\title{
GREGARIOUSNESS DURING SETTLEMENT IN THE BARNACLE ELMINIUS MODESTUS DARWIN
}

\author{
By E. W. Knight-Jones and J. P. Stevenson \\ Fisheries Laboratory, Burnham-on-Crouch, Essex
}

(Text-figs. I-3)

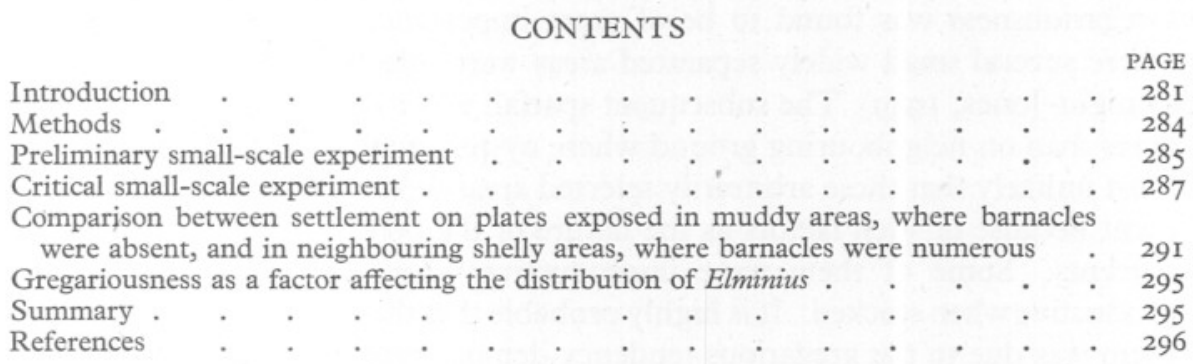

\section{INTRODUCTION}

Many species of marine animals have been described as local or gregarious. Jeffreys (1863-9) and Eales (1939), for instance, made occasional use of the latter term. It implies crowding, often in a restricted habitat, usually in a search for food or shelter. Such crowding must facilitate breeding. Thorson (1946) reviewed the evidence that even non-copulatory species are stimulated to spawn by crowding, and quoted a few observations suggesting that certain forms specifically seek the company of their fellows. In the present account the term gregariousness will be reserved for such behaviour, rather than for automatic crowding in restricted habitats.

Thorson also reviewed the gradually accumulating evidence that the settlement of marine larvae at the end of their planktonic phase is generally not haphazard. The idea of 'hit-or-miss' settlement advanced, for instance, by Colman (1933), for several species, including barnacles, is now out of date. Surprising powers of discrimination have been revealed in certain forms, but up to the present time, so far as we are aware, the only larvae shown to be gregarious during settlement are those of the oyster, Ostrea edulis. This was demonstrated by experiments in the oyster-breeding tanks of the Ministry of Agriculture and Fisheries at Conway (see Cole \& Knight-Jones, 1949). In those experiments, two or three times as many larvae attached themselves to shells which already bore recently settled oyster spat, as to similar shells from 
which all previously settled spat had been removed with the point of a needle. This happened consistently, day after day. In general, most larvae attached themselves to those shells which bore most spat, up to a density of from 50 to Ioo spat per shell. Once this density had been reached they settled apparently at random upon the more and the less crowded shells, but much less readily on the bare ones. The gregarious tendency was most marked when the spatfall was light. When numerous larvae were settling they quickly covered both spatshells and bare shells alike.

Spärck's (1949) observations in the Limfjord tended to confirm that oysters are gregarious during settlement, 'since restocking only took place in any considerable degree in places where the density of the left native stock was fairly great and since the continued restocking slowly spread from these places'. Gregariousness was found to be of great importance on Essex oyster beds, where several small widely separated areas were selected and heavily stocked (Knight-Jones, 1949). The subsequent spatfall was much more heavy on these areas than on neighbouring ground where oysters were sparse or absent. It is most unlikely that these arbitrarily selected areas were more suitable for settlement because of such factors as the nature of the bottom or exposure to tidal currents. Some of them were unproductive when unstocked but became productive when stocked. It is highly probable that the heavier settlement upon them was due to the gregarious tendency demonstrated by the critical experiments in the Conway tanks.

Lest it seem incredible that small, simply organized, planktonic larvae should be capable of such behaviour, it may be explained that the mechanism of gregariousness in $O$. edulis need not necessarily be very complex. Larvae which have reached the stage at which they are ready to settle crawl, by means of a ciliated and very mobile foot, upon any substratum with which they may happen to come into contact (Cole \& Knight-Jones, 1939). After crawling for a period they usually swim off again. Their discriminatory powers suggest that they can to some extent postpone attachment until they happen to find a place particularly favourable for it. In Essex creeks tidal currents carry swimming larvae several miles in a few hours, enabling those ready to settle to visit a variety of widely separated places. It appears that the presence of other oysters is one of the factors which encourage settlement. The stimulus may perhaps be olfactory, but there is no evidence on this point from work on oysters. On the other hand, laboratory experiments on ascidian larvae (Grave \& Nicoll, I940; Grave, I94I) showed that metamorphosis was hastened by crowding and also by aqueous extracts of larvae, later developmental stages, and adult tissues. It may therefore be expected that ascidian larvae will prove to be gregarious during settlement, stimulated by the water-borne secretions of their fellows, but direct evidence of this has not yet been obtained in the field, so far as we are aware, though it is a matter of common observation that adult simple ascidians usually occur in clumps. 
Gregariousness during settlement must be of great biological importance to a sessile form, such as the oyster, in facilitating breeding. Moreover, the individual is likely to find, in a situation where the species is already established, suitable conditions for its own survival.

In the Burnham-on-Crouch district the most serious competitor of newly settled oyster spat is the barnacle Elminius modestus, a recent immigrant from the Antipodes (Knight-Jones, I948). Smooth slates, which were exposed for weekly periods during the summers of I947, I948 and I949 to record the settlement of oyster larvae, were usually covered with these barnacles in a few days. When settlement was very intense the distribution of the barnacles over the surface of a slate was remarkably even. When settlement was light the barnacles tended to settle first in groups but, as colonization of the surface proceeded, the later arrivals rarely settled amongst the grouped individuals but rather upon the bare areas in between the groups. In this way their distribution gradually became even, provided the light settlement was sufficiently prolonged. Like many other barnacles Elminius settles particularly abundantly in scratches or irregularities of the surface, but the test-slates used were smooth, and the initial formation of the groups generally appeared to be unrelated to surface irregularities. The impression gained was that the early arrivals on the bare surfaces were gregarious but that the later arrivals on the crowded surfaces tended to space themselves out. Another point which appeared significant was that slates exposed at certain places consistently caught very few barnacles, though settlement elsewhere was very intense and cyprids were abundant in all plankton samples. The only feature which these places appeared to have in common was a bottom of bare mud, from which barnacles were absent. The slates on which settlement was heavy were from places where the bottom was covered with shells, on which Elminius was abundant. It seemed possible that gregariousness might have been responsible for the differences observed.

There is plenty of evidence suggesting that settling barnacles have considerable powers of discrimination. The literature is too lengthy to review here, but it seems particularly relevant to note that Visscher (I928) observed cyprids of Balanus improvisus and B. amphitrite crawling over the substratum for distances of more than $\mathrm{I} 2 \mathrm{~mm}$. and periods of over an hour, apparently testing different areas in a search for a place for attachment. B. amphitrite had been observed to attach within 7 days after hatching, yet Visscher kept some cyprids of this species under observation for Io or II days. By then some had attached but many were still active, which suggests that metamorphosis in this species can be delayed if conditions are unfavourable for attachment. One of us (E. W. K. J.) has observed that cyprids of $B$. balanoides, which had been attached anteriorly to the side of a glass vessel and dislodged by a jet of water from a pipette, were capable of swimming about and then attaching themselves again. Burton (I949) wrote 'the first settled larvae (of Balanus) seem to attract others to settle in the same spot'. Dr D. J. Crisp and Dr P. N. J. Chipperfield, with whom we had the 
good fortune to discuss this subject, kindly informed us that field observations had led them to suppose that barnacles might well be gregarious, but that they had also observed that barnacles often settled alongside surface projections, as though the cyprids had been sheltering there from currents. The tendency to settle in groups upon a uniform surface might therefore be due wholly to the later arrivals obtaining some shelter amongst previously settled barnacles. If so it could not accurately be described as gregariousness.

This point is of considerable practical importance in oyster research. The extremely productive French oyster industry is based on the use of artificial collectors for spat (see, for instance, Dalido, I948). Experiments with such collectors in Essex creeks have shown promising results, and the chief factor militating against their successful use there is the overwhelming prolific Elminius. Critical tests for gregariousness in Elminius were therefore carried out, with the positive results recorded here, as part of a study of its settlement behaviour. Further work will be directed towards finding out how far the smothering of collectors by barnacles can be delayed by placing them far from shelly shores where the barnacles are abundant. It is also hoped to offer for publication later some information regarding the spacing-out tendency on crowded surfaces.

It would be interesting to carry out critical experiments on other barnacles. Should a gregarious habit prove general it would have a bearing on the problem of ships' fouling, for it might prove worth while to take special measures for the cleaning of docks and wharves. Without gregariousness this would appear to be useless so far as organisms with lengthy planktonic stages are concerned.

\section{MeTHODS}

Small concrete slabs were prepared, each of which held a pair of rectangular plates of smooth glass (Fig. I). The plates, which measured $23.8 \times 13.3 \mathrm{~cm}$., were held on each side by a long coach-bolt, the head of which was embedded in the concrete. They rested horizontally upon the nuts of the bolts, $4 \mathrm{~cm}$. above the upper surface of the slab, and were secured by rubber washers, cut from pressure-tubing. Wire hoops protected the plates and served as carrying handles.

For the small-scale experiments the slabs were buoyed and placed close together below L.W.E.S.T., near Burnham. For the comparison between settlement on muddy and shelly shores they were placed at L.W.O.T., near Paglesham. They were exposed for short periods during late July, August and September I949. By then the main settlement of Elminius, which had occurred as usual during June and early July, was over. Settlement during the period of the experiments was moderate or sparse. In this respect conditions were ideal for testing for gregariousness, in that the spacing-out tendency observed at times of heavy settlement (see above) scarcely came into effect. 
A wire counting-frame and a hand-lens were used for counting. In the small-scale experiments counts were made of the barnacles which had settled on certain areas of the plates, details of which are given below and on p. 289. We have not yet learned to distinguish the earliest settled stages of Elminius modestus from those of Balanus improvisus, which they resemble in size, but we are confident that the results presented here relate to Elminius modestus, since plates exposed at the time of these experiments and under similar conditions, but for longer periods, became covered with the characteristically shaped Elminius, amongst which were very few Balanus improvisus. Over $99 \%$ of the barnacles settling at this time on test plates on or near the shore were Elminius.

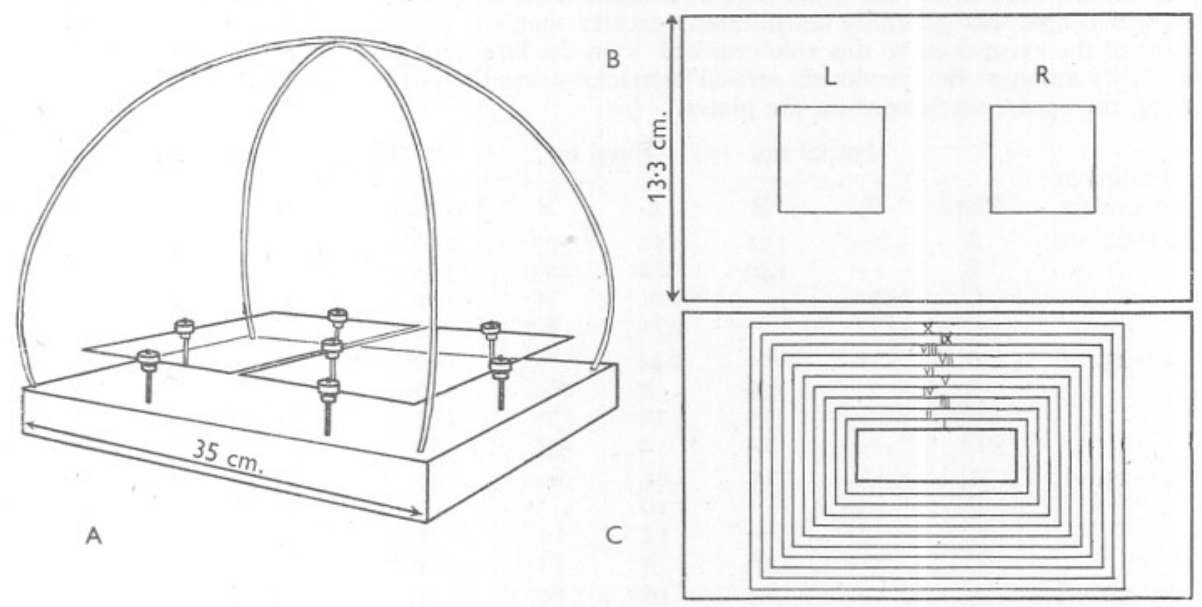

Fig. I. A, concrete slab, with protecting wire hoops, holding a pair of rectangular glass plates; $\mathrm{B}$, plate marked with areas $5 \mathrm{~cm}$. square, $\mathrm{L}$ and $\mathrm{R}$, for preliminary small-scale experiment; C, plate with microscope slide stuck to it. These were exposed in pairs, one with the slide barnacled, the other with the slide bare. When counting the barnacles which settled subsequently, each plate was placed over graph paper marked with the rectangles I-X, and the numbers settling on each narrow area at gradually increasing distances from the slide were obtained. Mean densities on these areas are shown in Fig. 2.

\section{PRELIMINARY SMALL-SCALE EXPERIMENT}

Two areas, $5 \mathrm{~cm}$. apart and each $5 \mathrm{~cm}$. square, were drawn with a diamond on each of four glass plates and marked respectively $\mathrm{L}$ and $\mathrm{R}$ (left and right, see Fig. I B). The plates were placed in position with the side which had been scratched by the diamond downwards. This orientation was adopted because it had previously been found that settlement on glass plates was much heavier on the upper than the lower surfaces. It was therefore decided to use the upper surfaces for small-scale experiments and it was desirable that this experimental surface should be uniformly smooth, since barnacles tend to settle in scratches and may well discriminate between scratches of various depths. The scratches delimiting the experimental squares could be clearly seen through the glass. 
The two slabs bearing the four plates were exposed to settling barnacles for a day. The entire lower surface of each plate and all the upper surface except for one of the $5 \mathrm{~cm}$. squares was then wiped with clean cotton-wool. The number of barnacles left in the square was counted and the remainder of the plate was examined to ensure that no barnacles had been left upon it. The plates were exposed for another day, the two slabs being placed near to one another.

\section{Table I. Settlement of Elminius modestus on Pairs of AREAS 5 CM. SQUARE}

Areas, $5 \mathrm{~cm}$. square, $\mathrm{L}$ and $\mathrm{R}$, marked on glass plates $\mathrm{A}, \mathrm{B}, \mathrm{C}$ and $\mathrm{D}$. Of each pair one area was initially bare whilst the other bore a recorded number of barnacles. The increment on the barnacled area was generally considerably greater than the number settling on the bare area. Most of the exceptions to this rule (marked $x$ in the last column) appear to have been due to mortality amongst the previously settled barnacles exceeding, in the later stages of the experiment, the sparse settlement on the plates.

\begin{tabular}{|c|c|c|c|c|c|c|c|c|c|}
\hline \multirow{2}{*}{$\begin{array}{l}\text { Period of } \\
\text { exposure }\end{array}$} & \multirow[b]{2}{*}{ Plate } & \multicolumn{2}{|c|}{ Initial no. } & \multicolumn{2}{|c|}{ Final no. } & \multicolumn{2}{|c|}{ Settlement } & \multirow{2}{*}{\multicolumn{2}{|c|}{$\begin{array}{c}\text { Ratio } \\
\text { Barnacled : bare }\end{array}$}} \\
\hline & & $\mathrm{L}$ & $\mathrm{R}$ & L & $\mathrm{R}$ & Barnacled & Bare & & \\
\hline \multirow[t]{4}{*}{$2 \mathrm{I}-22 . \mathrm{vii}$} & $\mathrm{A}$ & - & I3I & 152 & 595 & 464 & I52 & $3: I$ & \\
\hline & B & - & I 40 & 22 & 263 & 123 & 22 & $5 \cdot 6: I$ & \\
\hline & C & 132 & - & 271 & 35 & I39 & 35 & $4: I$ & \\
\hline & D & I77 & - & $47 \mathrm{I}$ & 82 & 294 & & $3 \cdot 6: I$ & \\
\hline \multirow[t]{4}{*}{$22-23 . v i i$} & A & 152 & - & $24 \mathrm{I}$ & I5 & 89 & I5 & $5 \cdot 9: 1$ & \\
\hline & B & - & I49 & 7 & I64 & I5 & 7 & $2 \cdot I: I$ & \\
\hline & C & - & 35 & I2 & 138 & 103 & I2 & $8 \cdot 6: I$ & \\
\hline & $\mathrm{D}$ & - & & 2 & 138 & 56 & 2 & $28: I$ & \\
\hline \multirow[t]{4}{*}{$23-25$. vii } & A & - & I5 & $8 \mathrm{I}$ & 64 & 49 & $8 \mathrm{I}$ & I $: I \cdot 7$ & \\
\hline & B & 7 & - & Io & 3 & 3 & 3 & I：I & $\times$ \\
\hline & C & I2 & $\overline{0}$ & II & I & $(-I)$ & I & - & $x$ \\
\hline & D & - & 48 & 3 & $6 \mathrm{I}$ & I3 & 3 & $4 \cdot 3: I$ & \\
\hline \multirow[t]{3}{*}{$25-26$. vii } & $\begin{array}{l}\mathrm{A} \\
\mathrm{B}\end{array}$ & 二 & 64 & I6 & 60 & $(-4)$ & I6 & - & $\times$ \\
\hline & $\stackrel{B}{C}$ & 10 & - & 2 I & 4 & II & 4 & $2 \cdot 7: I$ & \\
\hline & $\stackrel{C}{D}$ & II & $\overline{5 I}$ & 59 & I5 & 48 & I5 & $\begin{array}{r}3.2: 1 \\
2.0: 1\end{array}$ & \\
\hline \multirow{4}{*}{$26-27$. vii } & A & - & 60 & 26 & $\begin{array}{r}140 \\
73\end{array}$ & $\begin{array}{l}97 \\
13\end{array}$ & $\begin{array}{r}7 \\
26\end{array}$ & I : 2 & $\times$ \\
\hline & B & $2 \mathrm{I}$ & - & I7 & 4 & $(-4)$ & 4 & - & $\times$ \\
\hline & C & 59 & - & I27 & 4 & 68 & 4 & I7 : I & \\
\hline & D & 6 & - & 4 & 7 & $(-2)$ & 7 & - & $\times$ \\
\hline \multirow[t]{3}{*}{$27-28$. vii } & $\begin{array}{l}\mathrm{A} \\
\mathrm{B}\end{array}$ & 26 & - & $\stackrel{30}{\mathrm{Pl}}$ & lost ${ }^{3}$ & 4 & 3 & $\mathrm{I} \cdot 3: \mathrm{I}$ & \\
\hline & $\mathrm{C}$ & $\begin{array}{r}17 \\
\text { I } 27\end{array}$ & - & 99 & IO & $(-28)$ & IO & - & $\times$ \\
\hline & D & - & 7 & IO & 28 & $2 I$ & IO & $2 \cdot \mathrm{I}: \mathrm{I}$ & \\
\hline
\end{tabular}

At the beginning of this period each plate therefore presented to settling barnacles two similar squares, one of which was bare whilst the other contained a known number of barnacles. The object of the experiment was to compare the settlement on these squares. At the end of the day the number of barnacles on each square was counted. The results for this and subsequent days are given in Table I.

After counting, each plate was again wiped bare except for one of the squares, which was left barnacled. On a few occasions some of these barnacles were removed, with the object of making subsequent counting easier, and the number 
on the square recounted. The plates were then exposed for a further period. Where practicable the square left barnacled was that which had been wiped clean on the previous day. The number of times this change between the two squares $\mathrm{L}$ and $\mathrm{R}$ was effected for each of the plates can be deduced from Table I, where the plates are designated A, B, C and D.

Table I shows that, in general, settlement was much heavier on the squares which were initially barnacled than on those which were initially bare. A total of I6Io barnacles settled upon the former, 52I on the latter. During the first 2 days, when the initial numbers on the barnacled squares were fairly large and settlement was moderate, the ratios were consistently in favour of the barnacled squares. Later, when the initial numbers were smaller and settlement sparser, inconsistencies appeared, but even some of these supported the idea that the settling barnacles were gregarious. For instance, of the eighty-one barnacles which settled on the bare area of plate A on 23-25 July, sixty-nine settled in a small cluster in a corner of the square. In half of these inconsistencies the final number of barnacles on the barnacled square was less than the initial number, showing that mortality amongst settled barnacles was exceeding settlement. We have often seen evidence of mortality amongst young Elminius, and we are inclined to think that most of the inconsistencies in Table I were due to the mortality amongst the relatively large numbers of previously settled barnacles being great compared with the rather small numbers of new arrivals. Giving due weight to this point it is concluded that the squares which initially bore barnacles were considerably more favourable for settlement than those which were bare. This is not indisputable evidence for gregariousness. First, it does not answer the question whether the effect may not be due to mere sheltering amongst the previously settled barnacles, as amongst surface irregularities, and secondly, the bare surface was wiped immediately before exposure, whilst the barnacled surface had not been wiped for I or 2 days. Settling larvae of several forms have been shown to favour surfaces covered with bacterial or diatomaceous films (for references see Miller, Rapean \& Whedon, I948; Cole \& Knight-Jones, I949) and such films are acquired after short periods of immersion, though it is doubtful whether one affecting appreciably the behaviour of cyprids would be acquired in such short periods as a day or two.

\section{CRITICAL SMALL-SCALE EXPERIMENT}

A better experimental technique was derived from the account of settlement in Tubularia by Pyefinch \& Downing (1949), who set a glass microscope slide which bore a colony of Tubularia in the centre of a wooden panel and hung it from a raft which itself bore practically no Tubularia. A control exposure consisting of a bare slide set in the middle of a similar panel was immersed close beside it at the same time. Much heavier settlement subsequently occurred on the panel to which the Tubularia colony was attached (although 
this suggests gregarious behaviour it may have been due solely to larvae from the colony settling immediately after liberation).

Accordingly glass slides measuring $2.6 \times 7.5 \mathrm{~cm}$. were stuck with 'Durofix' adhesive to the centres of several glass plates. These were exposed to settling barnacles for a few days. They were then taken up and some were wiped thoroughly all over with clean cotton-wool, whilst others were wiped in the same way but leaving the slides barnacled. A pair of these plates was placed side by side, slides uppermost, in each concrete holder, one with the slide barnacled, the other with the slide bare. These pairs were exposed for periods of 2 or 3 days. After each period of exposure the numbers of barnacles on each slide and on the surrounding $199 \mathrm{~cm} .{ }^{2}$ of the upper surface of each plate were

\section{Table II. Settlement of Elminius modestus on Pairs of Glass Plates}

To one plate of each pair a microscope slide bearing a recorded number of barnacles was fixed, to the other a bare slide. Settlement was consistently much heavier on the plate which bore the barnacled slide.

\begin{tabular}{|c|c|c|c|c|c|c|c|}
\hline \multirow{3}{*}{$\begin{array}{l}\text { Period of } \\
\text { exposure }\end{array}$} & \multicolumn{4}{|c|}{ Plate with barnacled slide } & \multirow{2}{*}{\multicolumn{2}{|c|}{$\begin{array}{c}\text { Plate with bare } \\
\text { slide } \\
\text { Settlement }\end{array}$}} & \multirow{3}{*}{$\begin{array}{l}\text { Ratio in } \\
\text { favour of plate } \\
\text { with barna- } \\
\text { e cled slide }\end{array}$} \\
\hline & \multirow{2}{*}{$\begin{array}{c}\text { Initial no. } \\
\text { on slide }\end{array}$} & \multirow{2}{*}{$\begin{array}{l}\text { Final no. } \\
\text { on slide }\end{array}$} & \multicolumn{2}{|c|}{ Settlement } & & & \\
\hline & & & On slide & On plate & On slide & On plate & \\
\hline 6-8. viii & 212 & 287 & 75 & 480 & Plate & lost & - \\
\hline & 249 & 304 & 55 & 599 & 8 & I73 & $3 \cdot 5: I$ \\
\hline 8-IO. viii & 287 & 369 & 82 & $\begin{array}{l}354 \\
540\end{array}$ & $\begin{array}{l}3 \\
0\end{array}$ & 69 & $\begin{array}{l}5 \cdot 1: I \\
4 \cdot 6: I\end{array}$ \\
\hline & $\begin{array}{l}304 \\
369\end{array}$ & $\begin{array}{l}403 \\
4 I 3\end{array}$ & $\begin{array}{l}99 \\
44\end{array}$ & $\begin{array}{r}540 \\
66\end{array}$ & & & $\begin{array}{l}4 \cdot 6: I \\
2 \cdot I: I\end{array}$ \\
\hline ro-12. Vi11 & 403 & 413 & Plate lost & & $\begin{array}{r}14 \\
3\end{array}$ & $\begin{array}{l}31 \\
25\end{array}$ & $2 \cdot 1: 1$ \\
\hline I2-I4. viii & $\begin{array}{r}\mathrm{I} 4 \\
4 \mathrm{I} 3\end{array}$ & I & $\begin{array}{l}(-\mathrm{I} 3) \\
\text { Plate lost }\end{array}$ & 23 & $\begin{array}{l}0 \\
0\end{array}$ & $\begin{array}{l}7 \\
5\end{array}$ & $3 \cdot 3: I$ \\
\hline 3-6. ix & $\begin{array}{r}160 \\
85 \\
410\end{array}$ & $\begin{array}{r}167 \\
89 \\
497\end{array}$ & $\begin{array}{r}7 \\
4 \\
87\end{array}$ & $\begin{array}{l}\text { I4I } \\
\text { II } 6 \\
230\end{array}$ & $\begin{array}{l}\text { I } \\
\text { I } \\
5\end{array}$ & $\begin{array}{r}20 \\
24 \\
106\end{array}$ & $\begin{array}{l}6 \cdot 7: I \\
4 \cdot 8: I \\
2 \cdot 2: I\end{array}$ \\
\hline
\end{tabular}

recorded (see below for details of the counting-frame used), and the plates and one of the slides of each pair were again wiped bare before exposure for a further period. The results are set out in Table II.

Consistently, many more barnacles settled on the plate which bore the initially barnacled slide than on that which bore the initially bare slide. It seems highly probable that these differences were due to gregariousness. They cannot be regarded as due to sheltering, for the recently settled barnacles on the slide were small compared with the thickness of the slide $(2 \mathrm{~mm}$.), so that virtually the same degree of shelter was afforded by the bare slide as the barnacled slide. The increment on the barnacled slide was also consistently greater than the number settling on the bare slide, except for one occasion when no barnacles appeared on the bare slide whilst those on the barnacled slide were considerably reduced in number by mortality.

While counting, each plate was placed slide uppermost over graph paper on 
which the outline of the slide had been drawn surrounded by ten other concentric rectangles, gradually increasing in area (Fig. I C). The plate was orientated so that the slide was superimposed upon its outline on the paper. This outline measured $2.6 \times 7.5 \mathrm{~cm}$., the adjoining rectangle $3.5 \times 8.5$, the next $4.5 \times 9.5$, and so on. Between the outlines of adjoining rectangles there was therefore a series of areas, gradually increasing in size and distance from the slide, each $0.5 \mathrm{~cm}$. wide. The number of barnacles in each of these areas was recorded and is shown in Table III. The areas are numbered consecutively

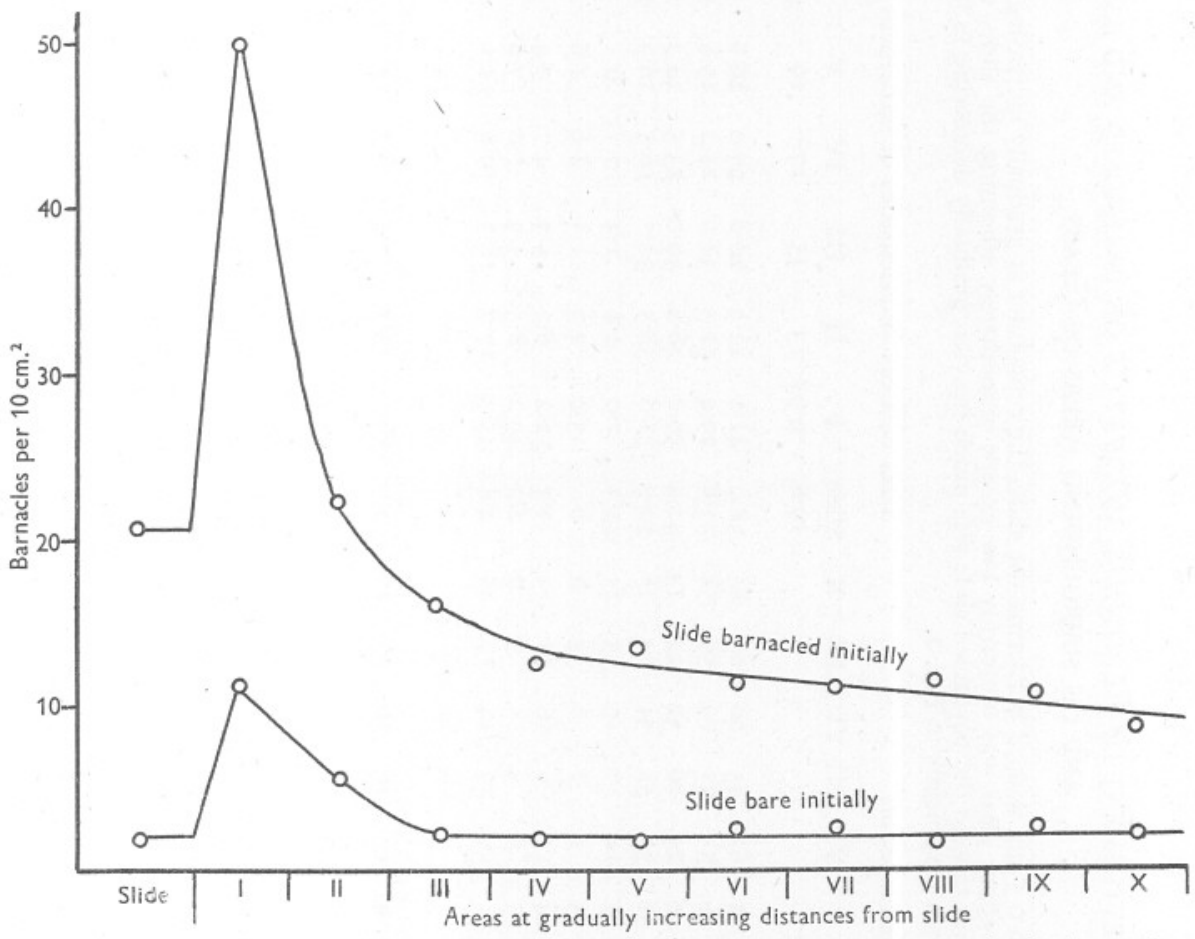

Fig. 2. Mean densities of settlement on slides and on surrounding areas at gradually increasing distances from them (see Fig. I c). Data from Table III.

I-X, I being that immediately surrounding the slide. The results relating to the barnacled slides and the bare slides are grouped separately. On the right of Table III the sizes of the areas and the densities of settlement on each are shown. Fig. 2 shows graphically the mean densities of settlement on the slides and at varying distances from them.

Considering first the plates with the slides which were initially bare, it will be seen that while the mean density of settlement on the slides and on the general surfaces of the plates was uniformly low, that on area II was more than twice as great and that on area I five times as great. Evidently the cyprids tended to shelter round the edges of the slides. The densities of settlement on 


\section{Table III. Densities of Settlement of Elminius modestus on barnacled and bare Microscope Slides}

AND ON SURROUNDING AREAS OF GLASS

Areas of glass were marked I-X, each $0.5 \mathrm{~cm}$. wide, I bordering the slide, the remainder at gradually increasing distances from it. Settlement on the initially bare slides and the surrounding glass was uniformly low except immediately adjoining the slide, where increased densities suggest a sheltering tendency. Settlement on and around the barnacled slide was much heavier, gradually decreasing in intensity with increasing distances from the slide. Mean densities are shown graphically in Fig. 2.

Nos. of barnacles on

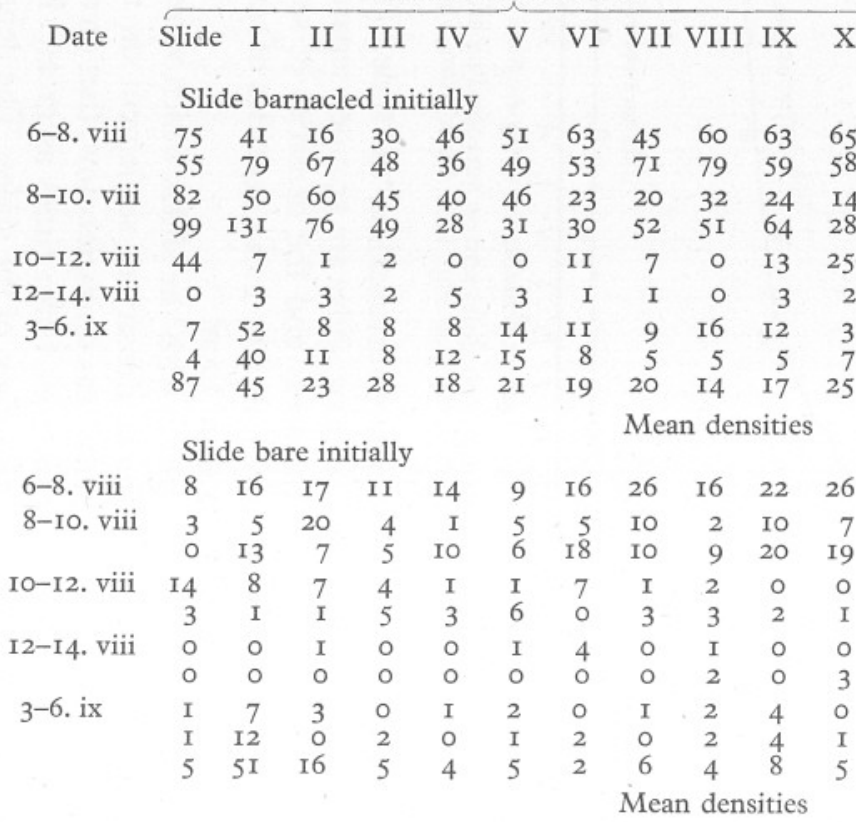

Sizes of areas and densities of settlement (nos. of barnacles per $10 \mathrm{~cm} .^{2}$ )

\begin{tabular}{|c|c|c|c|c|c|c|c|c|c|c|}
\hline Slide & I & II & III & IV & V & VI & VII & VIII & IX & X \\
\hline 19.8 & 9.95 & I3 & I5 & 17 & I9 & $2 I$ & 23 & 25 & 27 & $29 \mathrm{~cm}$ \\
\hline $\begin{array}{l}38 \cdot 0 \\
27 \cdot 8\end{array}$ & & $\begin{array}{l}12.3 \\
51.5\end{array}$ & $\begin{array}{l}20 \cdot 0 \\
32 \cdot 0\end{array}$ & & & & & & & $\begin{array}{l}22 \cdot 4 \\
20 \cdot 0\end{array}$ \\
\hline $\begin{array}{l}4 \mathrm{r} \cdot 4 \\
50 \cdot 0\end{array}$ & & $\begin{array}{l}46 \cdot 2 \\
58 \cdot 5\end{array}$ & & & & & & & & $4 \cdot 8$ \\
\hline $22 \cdot 3$ & $7 \cdot 0$ & 0.8 & $I \cdot 3$ & 0 & 0 & $5 \cdot 2$ & $3 \cdot 0$ & & $4 \cdot 8$ & 8.6 \\
\hline 0 & 3.0 & $2 \cdot 3$ & $I \cdot 3$ & $2 \cdot 9$ & $I \cdot 6$ & 0.5 & 0.4 & 0 & $I \cdot I$ & 0.7 \\
\hline $\begin{array}{l}3.5 \\
2.0 \\
4.4\end{array}$ & & $\begin{array}{r}6 \cdot 2 \\
8 \cdot 5 \\
17 \cdot 7\end{array}$ & $\begin{array}{r}5.3 \\
5.3 \\
18.7\end{array}$ & & $\begin{array}{r}7 \cdot 4 \\
7 \cdot 9 \\
\mathrm{II} \cdot \mathrm{I}\end{array}$ & & & & $\begin{array}{l}4 \cdot 4 \\
1 \cdot 8 \\
6 \cdot 3\end{array}$ & $\begin{array}{l}I \cdot 0 \\
2 \cdot 4 \\
8 \cdot 6\end{array}$ \\
\hline $20 \cdot 82$ & $50 \cdot 02$ & $22 \cdot 67$ & $16 \cdot 29$ & $12 \cdot 60$ & 13.46 & II $\cdot 58$ & II $\cdot$ IO & II $\cdot 42$ & 10.68 & 8.69 \\
\hline 4 & I6. I & & $7 \cdot 3$ & $8 \cdot 2$ & & & II. & & & $9 \cdot 0$ \\
\hline $\begin{array}{l}\mathrm{I} \cdot 5 \\
0\end{array}$ & $\begin{array}{r}5 \cdot 0 \\
13.1\end{array}$ & $\begin{array}{r}15.4 \\
5.4\end{array}$ & & & & & & & & $\begin{array}{l}2.4 \\
6.6\end{array}$ \\
\hline $\begin{array}{l}7 \cdot I \\
I \cdot 5\end{array}$ & $\begin{array}{l}8 \cdot 0 \\
I \cdot 0\end{array}$ & $\begin{array}{l}5.4 \\
0.8\end{array}$ & & & $\begin{array}{l}0.5 \\
3.2\end{array}$ & & $I \cdot 3$ & & $\begin{array}{l}0 \\
0.7\end{array}$ & $\begin{array}{l}0 \\
0.3\end{array}$ \\
\hline $\begin{array}{l}0 \\
0\end{array}$ & $\begin{array}{l}\circ \\
0\end{array}$ & $\begin{array}{l}0.8 \\
0\end{array}$ & $\begin{array}{l}\circ \\
0\end{array}$ & $\begin{array}{l}0 \\
0\end{array}$ & $\begin{array}{l}0.5 \\
0\end{array}$ & $\begin{array}{l}\mathrm{I} \cdot 9 \\
\mathrm{O}\end{array}$ & $\begin{array}{l}0 \\
0\end{array}$ & & 0 & $\begin{array}{l}0 \\
I \cdot O\end{array}$ \\
\hline $\begin{array}{l}0.5 \\
0.5 \\
2.5\end{array}$ & $\begin{array}{r}7 \cdot 0 \\
12 \cdot 0 \\
51 \cdot 3\end{array}$ & $\begin{array}{c}2 \cdot 3 \\
0 \\
12 \cdot 3\end{array}$ & $\begin{array}{l}0 \\
1 \cdot 3 \\
3 \cdot 3\end{array}$ & $\begin{array}{l}0.6 \\
0 \\
2 \cdot 4\end{array}$ & $\begin{array}{l}I \cdot I \\
0.5 \\
2 \cdot 6\end{array}$ & $\begin{array}{l}0 \\
1 \cdot 0 \\
1 \cdot 0\end{array}$ & $\begin{array}{l}0.4 \\
0 \\
2 \cdot 6\end{array}$ & & $\begin{array}{l}I \cdot 5 \\
1 \cdot 5 \\
3 \cdot 0\end{array}$ & $\begin{array}{l}0 \\
0 \cdot 3 \\
\text { I.7 }\end{array}$ \\
\hline I.96 & II 35 & 5.55 & $2 \cdot 39$ & 2.01 & I. 88 & 2.58 & 2.46 & $I \cdot 72$ & 2.59 & \\
\hline
\end{tabular}


the slides which were initially barnacled and on the plates which bore them were much greater. Also the mean density on the barnacled slides was twice that on the areas remote from the slides. On area I settlement was particularly intense and on II it was about as intense as on the slide, probably because the gregarious and sheltering tendencies were acting together in these areas. On III and subsequent areas the densities decreased gradually, as the distance from the slide increased. This gradual decrease contrasts strikingly with the uniformly low densities upon the plates with the bare slides. It suggests that gregariousness in Elminius is not entirely a habit of settling in small groups, perhaps as a result of contact between crawling cyprids and previously settled barnacles, but that it affects settlement at considerable distances. The results presented in the next section also support this conjecture, which seems plausible to us, since we are inclined to suppose that olfactory perception may be involved (though evidence on this point is lacking). It may be objected that if gregariousness is a response to the diffusion of a water-borne substance the intensity of settlement should vary inversely with the cube of the distance from the group of previously settled barnacles, but it seems unlikely that this relation would hold under the conditions of these experiments, in which the plates were exposed almost continuously to tidal currents of varying intensity.

\section{Comparison between Settlement on Plates exposed in Muddy Areas, Where Barnacles Were Absent, and in Neighbouring Shelly Areas, WHERE BARNACLES WERE NUMEROUS}

As already mentioned (p. 283) settlement of Elminius on test-slates used in routine work on oyster production was usually sparse at stations where the bottom was of bare mud. For example, Table IV gives the I 948 records for two such stations and for two other stations where shells (and barnacles) were abundant. The 1949 records showed a similar phenomenon. The length of river covered by these four stations is about 2 miles (Fig. 3), whilst the tidal currents cover over 4 miles on a moderate tide. Elminius cyprids were well distributed in plankton samples, so it seems unlikely that inequalities in their distribution could have been responsible for the differences in intensity of settlement in these areas. The slates were held horizontally about $5 \mathrm{~cm}$. clear of the bottom and did not catch much silt. The tidal currents at these stations seemed of similar strength.

Table V records the settlement on sets of glass plates placed on areas of bare mud and areas covered with shell about 50-100 m. apart. The sets on the Shop Laying each consisted of four plates, the others of two plates. They were put down at L.W.O.T., at places where patches of shell lying on the surface of the mud adjoined extensive areas of bare mud. The shores were fairly straight and uniformly sloping, and there were no differences between adjoining areas in respect of exposure to currents or wavelets. At least one of the patches of shell, 
that on Potton shore, had been made within recent years by dredgermen dumping ashore Crepidula (the American slipper limpet), and it is probable that most of the patches were originally man-made.

\section{Table IV. Settlement of Elminius modestus on Smooth Slates}

Numbers counted on slates (upper/lower surfaces) exposed just below L.W.E.S.T. for weekly periods at four stations near Paglesham, in 1948. Settlement was usually sparser at stations where the bottom was of bare mud.

\begin{tabular}{|c|c|c|c|c|}
\hline \multirow[b]{2}{*}{$\begin{array}{l}\text { Period of } \\
\text { exposure }\end{array}$} & \multicolumn{2}{|c|}{ Areas of shell } & \multirow{2}{*}{$\begin{array}{c}\text { Upper } \\
\text { Paglesham } \\
\text { Pool }\end{array}$} & \multirow{2}{*}{$\begin{array}{c}\text { Opposite } \\
\text { Potton point }\end{array}$} \\
\hline & Broadrakes & Shop laying & & \\
\hline $8-17$. vi & I88/516 & $714 / 916$ & $\mathrm{I} 4 / 8$ & No record \\
\hline I7-24. vi & $404 / 2705$ & $467 / 282$ & $210 /$ Ior6 & $0 / 0$ \\
\hline 24. vi-I. vii & $24 / 64$ & $53 / 10$ & $7 / 58$ & $0 / 0$ \\
\hline I-8. vii & $47 / 107$ & $22 / 44$ & I/O & $0 / 1$ \\
\hline $8-15$. vii & $\mathrm{I} / \mathrm{I}$ & $26 / 64$ & No record & $0 / 0$ \\
\hline I5-22. vii & $9 / 39$ & $118 / 136$ & $\mathrm{I} / 7$ & $77 / 43$ \\
\hline 22-29. vii & $203 / 77$ & $1740 / 899$ & $0 / 0$ & $308 / 80$ \\
\hline 29. vii-5. viii & $35 / 45$ & I029/349 & $0 / 0$ & $96 / 92$ \\
\hline 5-I2. viii & $24 / 42$ & $3 / 2$ & $1 / 0$ & $93 / 24$ \\
\hline 12-19. viii & $22 / 15$ & IO/II & $0 / 0$ & $\mathrm{I} / 2$ \\
\hline I9-24. viii & $2 / 2$ & $\mathrm{I} / \mathrm{I}$ & $0 / 0$ & $\mathrm{I}_{3} / \mathrm{I}$ \\
\hline Means & $87 \cdot 2 / 328 \cdot 5$ & $380 \cdot 3 / 246 \cdot 7$ & $23.4 / 108.9$ & $58 \cdot 8 / 24 \cdot 3$ \\
\hline
\end{tabular}

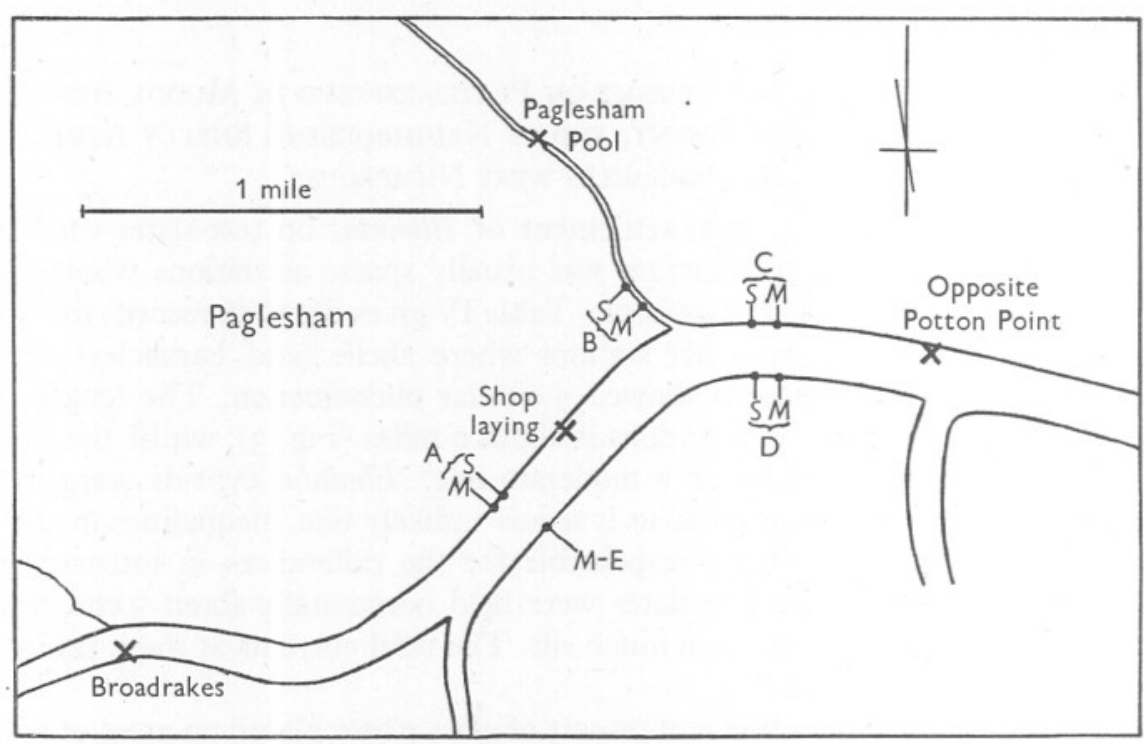

Fig. 3. River Roach near Paglesham at L.w.o.T., showing stations $(X)$ referred to in Table IV. Also, A to D, shore stations referred to in Table V, at each of which plates were exposed on areas of mud $(M)$ and shell $(S)$; E, muddy area on Potton shore at which plates were exposed for 8 weeks for comparison with plates exposed for the same period on the area of shell at A (p. 294).

Settlement on the plates exposed on the patches of shell was consistently much heavier than on those on adjoining bare mud. The difference was not due 
Table V. Comparison between Settlement of Barnacles on Glass Plates exposed at l.w.o.t., ON NEIGHBOURING AREAS OF SHELl AND MUD

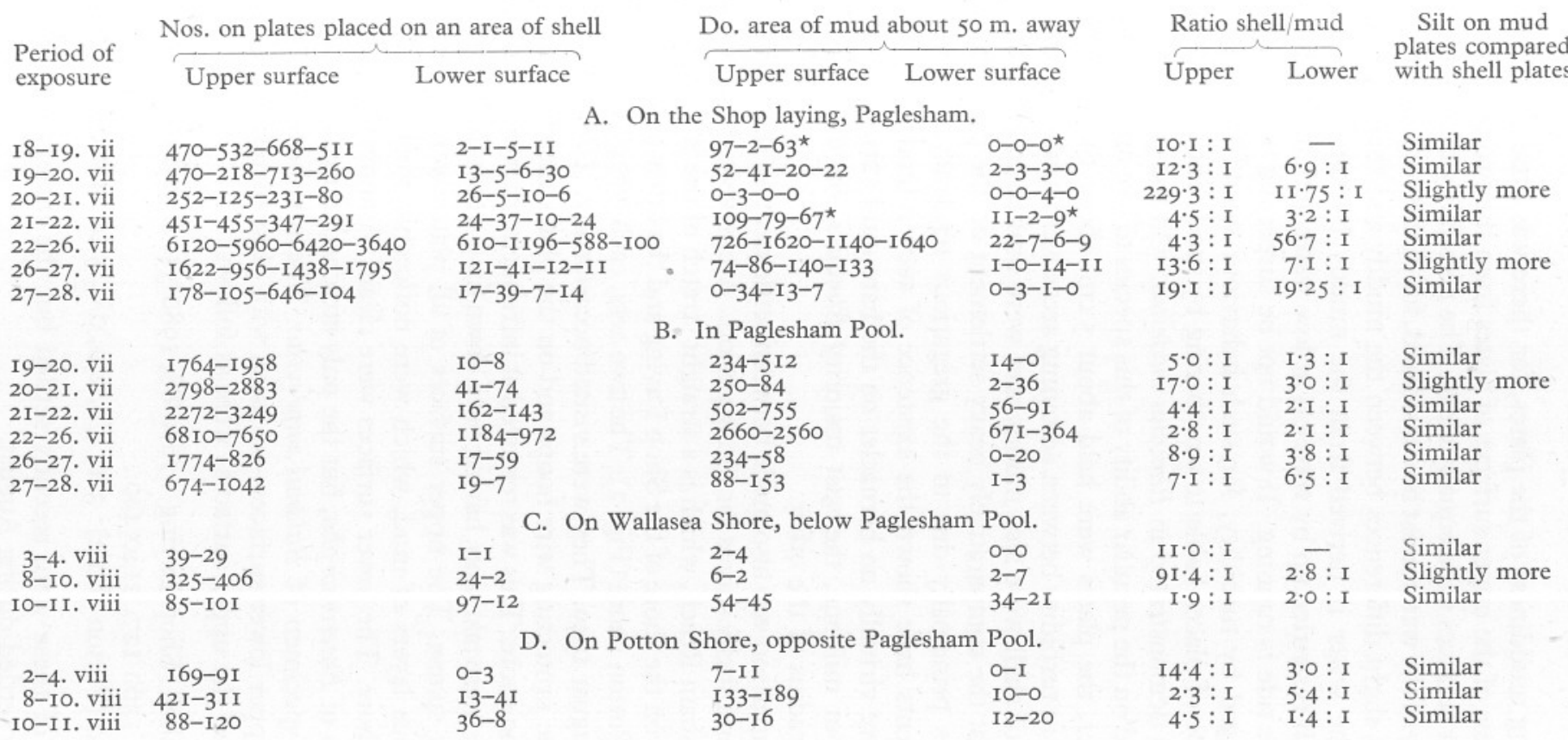

* One plate missing. This was allowed for when calculating ratios. 
to varying muddiness of the plates, for there was little difference between the muddiness of the upper surfaces of plates from the two types of ground, whilst the lower surfaces were equally clean. The possibility that it was due to varying turbidity of the water must be considered, for in this respect there were probably frequent slight differences between the muddy and shelly areas. Much of the silt in the water is derived from the muddy bottom, particularly from the shores. It is swirled up by wavelets at low water and, in places, by the current when the tide is running. It would not be surprising to find that settlement is discouraged by turbidity, for such behaviour would be adaptive, leading to avoidance of places liable to smothering by mud, but such behaviour has not yet been demonstrated in Elminius modestus. On the contrary, Darwin (I854) remarked on the peculiar ability of this species to live under muddy conditions. Moreover, the plates were held about $5 \mathrm{~cm}$. above the bottom, and the differences in turbidity between adjoining areas were probably small, because the patches of shell were also muddy and were limited in area. It is much more likely that the comparatively heavy settlement on the plates from the areas of shell was principally due to the gregarious tendency, since the small-scale experiments have shown the existence of such a tendency. At each locality there were virtually no barnacles on the bare mud surrounding the one set of plates, but millions, the vast majority Elminius, on the shells within a few metres' radius of the other.

A comparison was also made between settlement on sets of plates exposed on muddy and shelly shores for a long period. Areas were chosen on opposite sides of Paglesham Reach, which is a straight stretch of the River Roach. The shelly area was on the shore of the Shop Laying and the other on the almost uniformly muddy Potton shore (Fig. 3). The two sets, each of eight plates, were put out on I2 August 1949. They were visited occasionally. Ulva was found to collect round the protecting wire hoops and on the plates themselves, particularly on the Potton shore. This was removed at infrequent intervals. On 7 October 1949 the plates were taken up, having been down for 8 weeks during which settlement was very sparse. The upper surfaces of all plates were covered with almost continuous layers of mud, which were noticeably thicker on the plates from Potton shore. The lower surfaces were clean. Amongst the mud were sparse filaments of Enteromorpha, but the only attached animal, besides Elminius, was a single specimen of Balanus improvisus. The numbers of Elminius on these plates (upper/lower surfaces-as usual with glass plates, settlement was much heavier on the upper surfaces) were as follows:

Area of shell (Shop Laying): I680/88, I980/55, I270/213, I620/500, I560/III, 970/280, 1360/127, 2140/480.

Bare mud (Potton shore): 3/I, 2/2, 2/0, o/0, 5/0, 24/0, I/o, o/2.

Some of these were recently settled but the majority were large and had probably settled during August. 
These great differences could not have been due to the greater muddiness of the Potton shore plates, since the lower surfaces of all plates were equally clean. It is doubtful whether differences in turbidity contributed to them and though it is quite likely that they were partially due to greater blanketing of the Potton shore plates by Ulva, they were probably largely due to the gregarious tendency.

\section{Gregariousness as a FACTOR AFFeCting the Distribution of ELMINIUS}

Elminius is abundant on the shores of Essex creeks and becomes very crowded on stable substrata, such as pier piles. It is a small, short-lived form which achieves population densities even greater than those of native shore barnacles, since its individuals readily settle one on top of the other. Doubtless its gregarious habit during settlement tends to maintain its littoral distribution.

Away from the shores, at depths of about 5 fathoms for instance, it is comparatively sparse. The majority of shells dredged from these deeper grounds in I949 bore no Elminius, but occasional shells bore many; isolated individuals were rare. In November 1947, Elminius was well established, but not common, in the Helford River, Cornwall. On the shore at Calamansack only about one stone in twenty bore any specimens, but some bore groups of from five to twenty. Several isolated individuals were observed in this locality. It was even less common on the oyster-layings in mid-river, where only about one shell in a hundred bore any specimens, yet one shell was observed bearing a group of eight. In the Fal and Truro Rivers few were seen during a week's survey of shores and oyster grounds in June I949, except at the wharf at Malpas, where the species was abundant.

The tendency to settle in groups and in places where the species is well established must tend to prevent wastage through individuals settling in unsuitable localities and in isolation. It will not prevent the colonization of new areas, for occasional individuals settle in such areas even when settlement is sparse. Groups will gradually form round the majority of these pioneers, so that their breeding capacity will not be wasted and suitable areas will eventually become fully colonized. Far from restricting the spread of Elminius in this country, gregariousness will make it more certain, though more gradual. Craft in Essex creeks become heavily fouled with Elminius during the summer, and coastal shipping must play an important part in widening its distribution. This fact, together with the gregarious tendency, may partially account for its apparent predilection for wharves, although this is doubtless largely due to intolerance of wave action and insolation.

\section{SUMMARY}

A gregarious tendency during settlement, similar to that already demonstrated in oyster larvae, was suspected in Elminius, because cyprids settled in groups during the initial stages of colonization of surfaces (crowded later arrivals 
showed a spacing-out tendency) and because settlement on test-plates was peculiarly sparse at stations with a muddy bottom, where barnacles were absent.

Settlement was much heavier on areas of smooth glass, which already bore recently settled barnacles, than on similar adjoining areas which were bare.

When barnacled microscope slides were stuck to one set of glass plates, bare slides to another and the two sets exposed side by side, settlement was consistently much heavier on the plates which bore the barnacled slides. The mean density of settlement on the bare slides and the surrounding plates was uniformly low, except for a greater density immediately adjoining the slides, probably due to sheltering alongside their edges. On the barnacled slides density of settlement was much higher and on the plates immediately alongside still more so, whilst at increasing distances from the slides it became gradually smaller but was still much heavier than on the plates with the bare slides. This suggests that the sensory basis for gregariousness can act at a distance. It may possibly be olfactory.

Settlement was very much heavier on glass plates placed on areas of shore where shells were numerous and barnacles abundant, than on similar plates on areas of bare mud 50-100 m. away, where barnacles were absent. This was probably largely because of gregariousness.

In localities where the species was sparse it usually occurred in small groups, loss of breeding potential through isolation being thus at a minimum.

\section{REFERENCES}

BuRToN, M., I949. Observations on littoral sponges, including the supposed swarming of larvae, movement and coalescence in mature individuals, longevity and death. Proc. Zool. Soc. London, Vol. Ir 8, pp. 893-915.

Cole, H. A. \& Knight-Jones, E. W., 1939. Some observations and experiments on the setting behaviour of larvae of Ostrea edulis. Fourn. Cons. Int. Explor. Mer, Vol. I4, pp. 86-105.

Cole, H. A. \& Knight-Jones, E. W., 1949. The setting behaviour of larvae of the European flat oyster, Ostrea edulis L., and its influence on methods of cultivation and spat collection. Fish. Invest., Ser. II, Vol. 17, No. 3 .

Colman, J., I933. The nature of the intertidal zonation of plants and animals. Fourn. Mar. Biol. Assoc., Vol. I8, pp. 435-76.

Dalido, P., I948. L'huitre de Morbihan. Paris.

DarwIN, C., I854. A monograph of the Sub-class Cirripedia. II. The Balanidae, the Verrucidae. London: Ray Society.

Eales, N. B., 1939. The Littoral Fauna of Great Britain. Cambridge.

Grave, C., I94I. Further studies on the metamorphosis of ascidian larvae. Biol. Bull. Woods Hole, Vol. 8I, pp. 286-7.

Grave, C. \& Nicoll, P. A., I940. Studies of larval life and metamorphosis in Ascidia nigra and species of Polyandrocarpa. Pap. Tortugas Lab. Wash., Vol. 32, pp. I-46.

Jefrreys, J. G., 1863-9. British Conchology. London.

KNIGHT-Jones, E. W., I948. Elminius modestus: another imported pest of east coast oyster beds. Nature, Vol. I6I, p. 201. 
*Knight-Jones, E. W., I949. Aspects of the setting behaviour of larvae of Ostrea edulis on Essex oyster beds. Report to the Special Scientific Meeting on Shellfish of the International Council for the Exploration of the Sea, Edinburgh, October 1949.

Miller, M. A., Rapean, J. C. \& Whedon, W. F., I948. The role of slime film in the attachment of fouling organisms. Biol. Bull. Woods Hole, Vol. 94, pp. I43-57.

Pyefinch, K. A. \& Downing, F. S., I949. Notes on the general biology of Tubularia larynx Ellis and Solander. Fourn. Mar. Biol. Assoc., Vol. 28, pp. 2I-43.

*SpÄrCK, R., I949. Fluctuations in the stock of oysters (Ostrea edulis) in the Limfjord in recent times. Report to the Special Scientific Meeting on Shellfish of the International Council for the Exploration of the Sea, Edinburgh, October I949.

Thorson, G., I946. Reproduction and larval development of Danish marine bottom invertebrates, with special reference to the planktonic larvae in the Sound (Øresund). Medd. Komm. Danmarks Fisk. Havunde., Ser. Plankton, Bd. 4, Nr. I, 523 pp.

VISSCHER, J. P., I928. Reactions of the cyprid larvae of barnacles at the time of attachment. Biol. Bull. Woods Hole, Vol. 54, pp. 327-35.

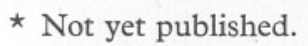

